\section{AMERICAN-EURASIAN JOURNAL OF SUSTAINABLE AGRICULTURE}

ISSN: 1995-0748, EISSN: 1998-1074

2019, volume (13), issue (2):pages (77-84)

DOI: 10.22587/aejsa.2019.13.2.9

Published Online in June http://www.aensiweb.com/AEJSA/

\title{
Adoption Level of Complete Feed Technology And Institution of Goat Farmers Group
}

\author{
Tanri Giling Rasyid ${ }^{1}$, Amrullah $^{2}$, Muhammad Aminawar ${ }^{3}$, ST. Rohani ${ }^{4}$, Muhammad Darwis $^{5}$ \\ 1,2,3,4 Faculty of Animal Science, Hasanuddin University. \\ ${ }^{5}$ Center for Research and Development of the Dynamics of Society, Culture and Humanities Institute for Research and Community Service \\ Hasanuddin University Street Perintis Kemerdekaan KM. 10 Tamalanrea, Makassar, South Sulawesi Province-Indonesia.
}

Received date: 12 February 2019, Accepted date: 15 May 2019, Online date: 3 June 2019

Address for Correspondence:

Tanri Giling Rasyid ${ }^{1}$, Faculty of Animal Science, Hasanuddin University.

E-mail:tanri.giling@gmail.com

Copyright $@ 2019$ by authors and American-Eurasian Network for Scientific Information.

This work is licensed under the Creative Commons Attribution International License (CC BY).

http://creativecommons.org/licenses/by/4.0/

\section{c) (i) Open Access}

\begin{abstract}
Goat livestock in Jeneponto Regency is one of the livestock species that are in high demand by the community and is one of the leading commodities, but the cultivation results from year to year have not shown a significant development due to the problems faced by farmers are limited feed and the role of farmer group organizations. The solution to overcome these problems is by formulating a complete feed from agricultural waste and strengthening institutional farmers through coaching. This study aims (1) to determine the level of adoption of comprehensive feed technology and (2) to determine the institutional group of goat farmers in Jeneponto Regency. The method used is descriptive research. From 11 districts in Jeneponto Regency, 3 districts were selected which had the largest goat population, Tamalatea District $(34,828$ tails), Bangkala West District $(23,274$ tails), and Bontoramba District (20,713 tails). Research samples from these 3 districts selected 25 people so that all of them were selected by 75 goat farmers. The sampling technique is simple random. Data collection was conducted through interviews, focus group discussions and using a Likert scale on every aspect measured, namely $1=10 \mathrm{w}, 2=\mathrm{medium}, 3=\mathrm{high}$ and analyzed descriptively statistically. The results showed that (1) the level of adoption of goat farmers on complete feed technology was in the high category namely availability of raw materials and complete feed fermentation, in the medium category namely mixing complete feed ingredients, while the low category was the availability of complete feed fermentation sites, and (2) evaluation of goat farmers on group institutions based on aspects of natural resources, aspects of human resources, aspects of financial resources, group organization, and group norms are in the high category.
\end{abstract}

KEYWORDS

Adoption, complete feed, institutions, farmers groups, goats

\section{INTRODUCTION}

The ability of goats to make use of forage as the main food ingredient into the meat, placing goats as a significant part of the national economy in general, as well as the welfare of rural families in particular. Goats are widespread in rural areas and are usually maintained to save lives or as cattle or dairy cattle for consumption by families and customary events besides their dung can be used for good fertilizer for plants. The high demand for goat livestock is a promising business opportunity so it is necessary to design a business model for the development of goat farms that can favor farmers and have an impact on increasing the income and welfare of farmers [1]. 
One of the livestock that is widely cultivated by the people in Jeneponto is goat which is one of the small ruminants that have very high benefits for humans, besides as a producer of meat, goats also have other benefits, namely as a producer of skin, milk, and feces as ingredients high-quality organic fertilizer.

Jeneponto Regency has potential in the development of goat livestock business because of the possibility of the region with sufficient land and feed availability, which is described in the form of a master plan and action plan. Therefore, based on the Spatial Plan, Jeneponto Regency is designated as a goat business development center which is determined by the Regent with measurable criteria [2]. According to [3], the requirements for livestock business development determined by Jeneponto Regency Head are able to contribute significantly or potentially high to goat production in Jeneponto Regency, facilitated by Regional Income and Expenditure Budgets of the district and supported by state budget, and supported by Regional Income and Expenditure Budgets of South Sulawesi Province.

An increase in goat livestock population is necessary and absolute to do, but the biggest challenge in all goat production systems is the availability of feed and land, whereas the main factor in determining the productivity of goats is the guaranteed availability of quality food for the weight gain of goats. To ensure the availability of quality feed, breakthroughs and technological support are needed that can be done by making a complete feed from agricultural waste. [4] Technology adoption fermented feed or complete feed that given as learning by doing to the farmers gives the attitude change to the cow cattle farmers knowledge from using field from as shepherded to used fermented feed or complete feed because it gives more benefit for the daily weight gain and the duration of cow cattle fattening is really in just in a short time and also it gives profit financially.

The process of making complete feed requires farmers' knowledge and skills. To improve the knowledge and skills of farmers, it is necessary to approach goat breeding groups for the development of goat livestock business to achieve productive economy can be carried out through participatory training interventions with patterns of learning by doing [5]. Institutional development of farmer groups can be carried out well if all aspects of institutional natural resources, human and financial resources (R); Organizations $(\mathrm{O})$ and Norms $(\mathrm{N})$ are well implemented to achieve common goals in groups.

This is the reason behind the implementation of this research which aims (1) to determine the level of adoption of complete feed technology and (2) to find out the institutions of the goat farmers groups based on aspects of resources (natural, human and financial), organization and norms in Jeneponto Regency.

\section{RESEARCH METHODS}

This research was conducted from May to July 2019 in Jeneponto Regency, South Sulawesi Province, Indonesia. The research method used is descriptive research. From 11 districts in Jeneponto Regency, 3 districts were selected which had the largest goat population, Tamalatea District (34,828 tails), Bangkala West District (23,274 tails), and Bontoramba District (20,713 tails) [6]. Research samples from these 3 districts selected 25 people so that all of them were selected by 75 goat farmers. The sampling technique is simple random. Data collection was conducted through interviews, focus group discussions and using a Likert scale on every aspect measured, namely 1 = low, 2 = medium, 3 = high and analyzed descriptively statistically [7]. The level of adoption of complete feed is measured based on the availability of raw material for feed, mixing feed ingredients, feed fermentation, availability of places for feed fermentation, while the institutional groups of farmers are measured based on natural resources, aspects of human resources, aspects of financial resources, group organizations, and norms groups with class ranges are as follows:

Highest score $=$ Highest weight $\mathrm{x}$ number of respondents $\mathrm{x}$ number of questions

Lowest score $\quad=$ Lowest weight $\mathrm{x}$ number of respondents $\mathrm{x}$ number of questions

$$
\text { (1) (75) }
$$

$$
=375
$$

Class range $\quad=$ Highest score - Lowest score

$$
\text { Number of Classes }
$$

$$
=\frac{1125-375}{3}=250
$$

From these values can be made in the following categories:

High $=875-1125$

Medium $=625-875$

Low $=375-625$ 


\section{Adoption Level of Complete Feed Technology}

From the results of interviews with 75 goat farmers, it is known that the level of adoption of complete feed technology is presented in Table 1.

Table 1. Level of Goat Farmer Adoption of Complete Feed Technology in Jeneponto Regency.

\begin{tabular}{|l|c|c|c|c|c|c|}
\hline \multirow{2}{*}{\multicolumn{2}{|c|}{ Complete Feed Technology }} & \multicolumn{5}{c|}{ Level of Adoption } \\
\cline { 2 - 7 } & \multicolumn{2}{|c|}{ High } & \multicolumn{2}{c|}{ Medium } & \multicolumn{2}{c|}{ Low } \\
\cline { 2 - 7 } & Org & $\%$ & Org & $\%$ & Org & $\%$ \\
\hline Availability / collection of complete feed raw materials & 40 & 53,3 & 29 & 38,7 & 6 & 8 \\
\hline Mixing complete feed ingredients & 18 & 24 & 50 & 66,7 & 7 & 9,3 \\
\hline Complete feed processing / fermentation & 57 & 75 & 14 & 18,4 & 5 & 6,6 \\
\hline Availability of a place for complete feed fermentation & 9 & 12 & 21 & 28 & 45 & 60 \\
\hline
\end{tabular}

Source: Primary Data After Processed, 2019.

Table 1 shows that the level of adoption of goat farmers on the level of adoption of complete feed technology which states a high level of availability/ collection of complete feed raw materials as many as 40 people $(53.3 \%)$, mixing complete feed ingredients 18 people $(24 \%)$, processing/fermentation of feed complete 57 people $(75 \%)$, and availability of complete feed fermentation sites for 9 people $(12 \%)$.

Goat farmers who stated that they were on the availability / collection of complete feed raw materials as many as 29 people $(38.7 \%)$, mixing complete feed ingredients 50 people $(66.7 \%)$, complete processing / fermentation of food 14 people (18.4\%), and availability of complete feed fermentation sites for 21 people $(28 \%)$.

While goat farmers who stated low on the availability/collection of complete feed ingredients 6 people (8\%), mixing complete feed ingredients 7 people (9.3\%), complete processing/fermentation of feeds 5 people $(6.6 \%)$, and availability a place for complete feed fermentation 45 people $(60 \%)$.

This shows that the technology of complete feed technology as goat feed is easy to understand by farmers in Jeneponto Regency so the adoption of complete feed technology is easy to implement, [8] Feed is a major component for the success of the cattle business. But there are difficulties in the availability of $60 \%$ complete feed fermentation. This is due to limited equipment and land as storage for feed ingredients in some farmers so that the implementation of complete feed processing should be carried out jointly with group members.

Maintaining goats is not difficult because the feed is quite diverse. Various types of forage can be consumed by goats. [9], which the types of leaves that are quite favoured by goats include turi leaves, lamtoro leaves, and jackfruit leaves.

Goat feed, in general, can be divided into two, namely, forage and concentrate feed. Forage feed can be in the form of natural grass, cultivated grass and legume leaves, while concentrate feed can be in the form of rice bran, corn bran and coconut cake.

The recommended feed for goats is high-energy, high-protein feed known as concentrate feed and forage plus fermented feed. Concentrated feed and fermentation are recommended because the raw material is widely available at the research site on the other hand with the nutritious feed. Goat can be large and fast can be marketed quickly.

The grass is a source of energy or energy for goats. The type of grass that is commonly given by livestock is natural grass (field grass). Types of grass that are cultivated (planted) include Setaria grass, brachiaria and clitoria ternatea. In addition to grass, the remaining agricultural products can also be used as a source of energy or energy, among others: rice bran, skin and cassava leaves, papaya leaves, kale stalks, corn leaves and rice straw. Feed as a good source of protein for the growth of goats, among others: peanut leaves, long bean leaves, soybean leaves, gamal leaves, turi leaves, lamtoro leaves and kaliandra leaves [10].

According to [11], the source of feed in dry land is quite diverse and varied, other than those sourced from grazing land or public land that has so far served as a supplier of animal feed forage. So that without any efforts to improve and preserve vegetation, there will be a decrease in the supply capacity. In connection with the increase in livestock populations without the exploration of feed sources, there will be a shortage of feed during the dry season, this is what often happens in dryland areas. Besides that, the land is still possible to be planted with high-yielding types of animal feed with criteria for drought resistance, high production and good nutritional content so that it will ensure continuity of animal feed throughout the year.

Goat feed needs can be met through the innovation of complete feed technology made from local raw materials from various agricultural crop straws and agricultural and plantation product processing wastes. In addition, complete feed made from local raw materials is a cheap type of feed, so it is very suitable for use by farmers. Complete feed requirements must be fulfilled by 3 main conditions, namely the availability of feed ingredients as a source of fiber, energy sources, and protein sources [12]. Feed ingredients as a source of fibre 
include rice straw and low-quality corn straw [13]. Feed ingredients as an energy source include rice bran, and raw material for protein sources including tofu dregs and coconut cake. The target of the target to be achieved in making complete feeds is the raw material available in the field with technology so that the quality can be improved at a low cost. By combining technology, capital, and resources in order to obtain optimum output [14] Therefore, the socio-economic and psychological variables substantially influencing the technology adoption of different enterprises must be taken into consideration while accelerating the pace of technology adoption under diversified farming system [15].

Farmer's perception of technological innovation is the process of organizing and interpreting the stimulus received by farmers, before the farmer takes the decision to accept or reject the innovation. [16] In the process of adoption, farmers, ranchers target take a decision after going through several stages. At first, the farmers-ranchers know the target of an innovation that could be something completely new or that has long been found but it is still new to the farmer-farmers target. If the farmer-farmers are implementing an innovation, the farmer-farmers that goal leaving the old ways.

According to [17], that the adoption of technology package is necessary to increase the scale of livestock. It is expected to increase goat productivity and achieve the growth rate of production as expected. Increasing the goat production by the improvement of maintenance technology packages such as technology of feed, reproductive, enclosure, and isease control components.

\section{Institution of Goat Farmers Group}

The measurement of the institutional role of goat farmers in Jeneponto Regency is based on three institutional aspects including resources, namely natural resources, human resources and financial resources, organization and norms. Based on the results of the study obtained by the assessment score of goat farmers on the institutional farmer groups can be seen in Table 2.

Table 2. Scoring Assessment of Goat Farmers to Farmer Group Institutions

\begin{tabular}{|c|c|c|c|c|c|}
\hline Number & Category & Score & $\begin{array}{l}\text { Frequency } \\
\text { (Person) }\end{array}$ & $\begin{array}{l}\text { Percentage } \\
(\%)\end{array}$ & $\begin{array}{c}\text { Value } \\
\text { (Score x Frequency) }\end{array}$ \\
\hline \multirow[t]{5}{*}{1.} & Natural resources & & & & \\
\hline & High & 3 & 60 & 80 & 180 \\
\hline & Medium & 2 & 10 & 13,3 & 20 \\
\hline & Low & 1 & 5 & 6,7 & 5 \\
\hline & Total & & 75 & 100 & 205 \\
\hline \multirow[t]{5}{*}{2.} & Human Resources & & & & \\
\hline & High & 3 & 65 & 86,6 & 195 \\
\hline & Medium & 2 & 8 & 10,7 & 16 \\
\hline & Low & 1 & 2 & 2,7 & 2 \\
\hline & Total & & 75 & 100 & 213 \\
\hline \multirow[t]{5}{*}{3.} & Financial resources & & & & \\
\hline & High & 3 & 66 & 88 & 198 \\
\hline & Medium & 2 & 7 & 9,3 & 14 \\
\hline & Low & 1 & 2 & 2,7 & 2 \\
\hline & Total & & 75 & 100 & 214 \\
\hline \multirow[t]{5}{*}{4.} & Group organization & & & & \\
\hline & High & 3 & 67 & 89,3 & 201 \\
\hline & Medium & 2 & 7 & 9,3 & 14 \\
\hline & Low & 1 & 1 & 1,4 & 1 \\
\hline & Total & & 75 & 100 & 216 \\
\hline \multirow[t]{6}{*}{5.} & Group norm & & & & \\
\hline & High & 3 & 63 & 84 & 189 \\
\hline & Medium & 2 & 11 & 14,6 & 22 \\
\hline & Low & 1 & 1 & 1,4 & 1 \\
\hline & Total & & 75 & 100 & 212 \\
\hline & & Score & & & 1060 \\
\hline
\end{tabular}

Source: Primary Data After Processed, 2019.

Table 2. shows that the total score of the assessment of the goat farmers group institution in Jeneponto Regency, which is $\mathbf{1 0 6 0}$ results, means that it is in the High category (875 - 1125). Based on the results of this research, it can be said that Jeneponto Regency has the potential of natural resources, which is very supportive of farmers business in goat farming. One of the natural resources owned in the area of land that will affect the level of goat production because the availability of feed is fulfilled throughout the year and naturally affects the efficiency of the goat livestock business. The greater the area of land for planting forage, the higher the availability of forage potential, and vice versa. According to [18] one of the important natural resources for goat 
farming in each region is the potential for land availability because the land is an ecological base for the growth of goat livestock is also a place of growing forage and as a place of business activities for goats. Land for livestock business in land that does not compete with food crops business.

Goat farmers as potential human resources, provide support for the business of goat livestock in Jeneponto Regency. [19] Human resource development can be done through training and mentoring strengthening. The approach to training goat farmers to develop goat farming to achieve productive economy can be done through participatory training interventions with learning patterns while doing.

The capability of farmer's capital as a potential resource that is still needed to support the business of goat livestock in Jeneponto Regency. [20] To develop financial resources can be done through group collaboration to be able to access capital assistance from banks and from the government.

Livestock farmer groups can be utilized by goat farmers to the fullest because the existence of livestock farmer groups can support the business of goat livestock in Jeneponto. Goat farmers can enjoy it as an institutional strengthening through the improvement and refinement of the statutes and bylaws, critical awareness training and direction of farmer groups. [3] in a goat farm business, goat farmers usually belong to groups. The goal is that the goat farmers who are members of the farmer-livestock group can cooperate with each other and become a dynamic and developing group. The influence of the social groups that were formed also differed, there were those that only affected their members, some affected the surrounding community, and some also affected the survival of the people or the city, so that they were able to realize the development program.

Goat farmers still need to apply to the maximum group norms for the development of goat livestock businesses in Jeneponto Regency. [3] Social groups that are traditionally formed on the basis of similarity in lineage separated social experiences and similar beliefs in religious beliefs tend to have level cohesiveness, but networks and trust ranges. which is built narrowly. On the contrary, in groups that are built on the basis of similarity in orientation and goals and with more modern organizational management characteristics, they will have a better level of member participation and have a wider network range and will have a positive impact on group progress and contribute to the development of society at large.

The role of farmer groups is crucial in the development of livestock businesses. The effort that needs to be developed in fostering and strengthening the farmers group is the institution of the farmers group. For this reason, an effective approach is needed so that farmers can utilize farmer groups through the growth of a sense of ownership, participation, creativity development, and community and local government support [21].

Farmer groups are farmers who are formed on the basis of common interests, similarities in environmental conditions (social, economic, resource) familiarity and harmony led by a chairman. The main role expected from the farmer group according to [22] is: (a) the farmer group is functioned as a central institution in the system that is built; the farmer group is used as the basis for the business of the farmers in each village; (b) to improve food security at the local level. In this way, poor farmers and food insecurity will increase their ability to overcome food problems and poverty in a group bond and group combination which is a vehicle to fight for the fate of its members in accordance with local aspirations, socioeconomic conditions and culture. Communities through farmer groups are also expected to be able to optimize the use of local resources to increase income and mutual welfare; and (c) the farmer group is considered as a Rural Economic Enterprise so that it can receive a Capital Strengthening Fund, which is a loan fund that can be used to buy farmers grain during the harvest, so the price does not fall too much.

The development of livestock farmer groups is directed at empowering its members to have independent power, capable of implementing innovation (technical, social and economic), able to utilize the principles of economies of scale and able to face business risks, so as to be able to obtain decent income and welfare. To carry out the function properly, the farmer / livestock group group acts as a teaching-learning class, production unit, vehicle for collaboration and business groups. According to [23] states that the role of livestock farmer groups in teaching and learning class activities is to plan and prepare learning needs, create a climate / learning environment, express and understand desires. As a production unit, it will be easier to develop to achieve an agribusiness-oriented economy. Procurement of production facilities, application of various innovations, processing and marketing of results can be carried out at a lower cost, and the products produced can be sold at a higher price, so that the profits of the livestock farming obtained by each member increase.

The role of livestock farmer groups as a vehicle for collaboration, according to [24], states that the role of livestock farmer groups as a vehicle for collaboration can be explained by the following forms of activities: (a) collect basic data and information: livestock farmer groups in this case similarly with the farmers collecting data and basic information (baseline data) about the potential of livestock businesses that will be pioneered in the future, can it provide positive benefits to improve the welfare level of farmers; (b) looking for Market Information: cooperation between fellow farmers in livestock farmer institutional activities that is by looking for market information, members in this case help the group to find market information produced can be marketed according to the desired price desired by farmers; and (c) Growing Motivation and Increasing the Interest of 
Farmer Farmers: In addition to forms of cooperative activities among farmers such as collecting basic data and information, searching for market information, also farmers in the group build cooperation in terms of growing motivation and increasing the interest of farmers to be willing and able to understand, understand, and adopt innovative technologies that are in accordance with the needs and conditions of the farming farmers in developing their businesses.

Livestock farmer groups that have carried out the above three functions well, are then directed to be able to seek and utilize various opportunities and business opportunities, as well as increase business towards the commercial, where activities carried out by the group have taken into account losses / profits. All of these can be well implemented and develop independently towards farmer/livestock groups as agribusiness-oriented businesses and can support businesses for production in farms / livestock. To achieve this, the farmer / livestock group as a forum for solving problems faced by farmer groups through guidance conducted by agricultural extension officers through the application of new innovations[23].

The role of livestock farmer groups is very important in increasing production where cooperation between farmer groups can give encouragement to farmers/farmers to want to change their ways of life according to the development of more advanced livestock technology. Sometimes several groups of farmers/farmers move beyond the type of mutual cooperation but collaborate in ways that are more organized and for a longer period of time to meet shared needs [21].

According to [1] stated that, one of the conditions for the acceleration of agricultural development was the existence of farmer group cooperation activities. Groups are a set or unit of human beings who live together so that there is a reciprocal and mutual influence and have an awareness to help each other. The natural tendency of the peasant community to go towards cooperation is very necessary to form a farmer group to be able to increase productivity and increase and a more even distribution of income. Some of the advantages of the formation of farmer groups are as follows: (a) the closer the interaction in the group is and the more the group leadership is established; (b) the more rapidly increasing focus on the soul of cooperation between farmers; (c) the faster the process of permeation diffusion of the application of new technological innovations; (d) the increasing ability of average farmers to repay loans to farmers; and (e) Increasing market orientation, both related to input and products.

The role of livestock farmer group institutions as a business group according to [1] is expected to be: (a) a gathering place for people who have similar goals to unite abilities (ideas, ideas, capital and others); (b) means of productive business that exist in the community, especially business opportunities from the operations of the company. In the period that allows this business group to be expected to be a "partner" of the company as a worker in the development of livestock business activities; (c) business facilities to provide additional input for community development through the provision of profits from livestock businesses; and (d) means of organizing the community in welcoming the coaching programs carried out by the company (the development of livestock businesses, accommodating members within the scope of the livestock farmer group).

According to [25], that in order to improve the quality of resources, organization, and norms. The provision of resources must be fulfilled such as infrastructure development, capital provision, and production facilities assistance, while community organizing includes group formation, institutional strengthening, and network development, then awareness includes reflection of problems and potential, self-help mapping and social mapping. From the description above, it can be made a general cycle of social preparation at the community level through identification of problems and potential, organizing and forming institutions, participatory program planning, program implementation, and monitoring and lesson learning as well as critical reflection and awareness.

\section{CONCLUSIONS}

From the results and discussion, it can be concluded that (1) the level of adoption of goat farmers on complete feed technology is in the high category, namely the availability of raw materials and complete feed fermentation, in the medium category namely mixing complete feed ingredients, while the low category is the availability of fermentation complete feed, and (2) evaluation of goat farmers on group institutions based on aspects of natural resources, aspects of human resources, aspects of financial resources, group organization, and group norms are in the high category.

From the results, discussion, and conclusions, it is recommended: (a) that farmers should use the potential of agricultural, plantation and forestry waste to meet the needs of goat feed through complete feed technology; (b) so that farmers more effectively and efficiently utilize the role of their group institutions for the survival of their goat livestock business.

\section{Acknowledgements}

Thank you to the Directorate of Research and Community Service, Directorate General of Research and Technology Strengthening Ministry of Research, Technology and Higher Education of the Republic of 
Indonesia who provided research funding assistance with the 2019 Higher Education Applied Research (PTUPT) scheme.

\section{REFERENCES}

[1]Rasyid, T.G., 2016. Alternative Model of Goat-Based Livestock Development Based on Socio-Economic in Majene District, West Sulawesi Province. Postgraduate Program of Hasanuddin University. Dissertation. Makassar.

[2]Rasyid, T.G., ST. Rohani, Muhammad Aminawar, 2017. Strengthening of Social Capital Institution and Its Impact on Development of Goat-Based Livestock Economy Based Business in Jeneponto Regency of South Sulawesi Province. First Year Report on Superior Research of Higher Education. Institute for Research and Community Service Hasanuddin University, Makassar.

[3]Rasyid, T.G., Rohani, M.Aminawar, and M.Darwis. 2018. The Level of Social Capital and its Effect on the Participation of Farmers on Goat Livestock Business Development in Jeneponto Regency South Sulawesi Provinsi-Indonesia. Advances In Environmental Biology. ISSN: 1995-0756, EISSN: 19981066, Februari 2018.

[4]Rasyid, T.G., Amrullah, S.N.Kasim, I.M.Saleh, and Rohani. 2018. Technology Adoption of Complete Feed by Cattle Cow Farmers. American-Eurasian Journal Of Sustainable Agriculture. ISSN: 1995-0748, EISSN: 1998-1074 2018, Volume (12), issue(1), pages(1-4), April 2018.

[5]Rasyid, T.G., S.N.Sirajuddin, and S.N.Kasim. 2016. Alternative Model for Development of Productive Economy for Goat Farmers in Majene District, West Sulawesi. Proceedings of the National Seminar and National Conference I PERSEPSI. Faculty of Animal Science, Gadjah Mada University, Yogyakarta.

[6]Jeneponto Regency Central Statistics Agency. 2017. Jeneponto Regency In Year Figures 2017. Office of the Central Statistics Agency of Jeneponto Regency, Jeneponto.

[7]Sugiyono. 2014. Statistics for Research. 24th Print. Alfabeta publisher, Bandung.

[8]Sirajuddin, S.N., A.Asnawi, S.Syawal, and M.Jamal. 2016. Response of Cattle Farmers to Rice Straw Silage in Soppeng Regency, South Sulawesi Province. American-Eurasian Journal Of Sustainable Agriculture. ISSN: 1995-0748, EISSN: 1998-1074 2016, Volume (10), issue(3), pages(33-36), September 2016.

[9]Pamungkas. 2009. Goat Livestock Cultivation. BPTP South Sumatera.

[10]Prabowo, A. 2010. Goat Livestock Cultivation. BPTP South Sumatera.

[11]Sasongko, W.R., Y.G.Bulu, and A.Surahman. 2012. Marginal Dry Land Utilization through Integration of Food Crops, Feed Plants, and Ruminants. Feed Forage and Pasture Cultivation Papers. Gajah Mada University. Yogyakarta. Retrieved May 22, 2015.

[12]Agus. 2012. Concentration Feed Materials for Cows. PT. Citra Aji Parama, Yogyakarta.

[13]Ako, A. 2012. Increased Production and Quality of Dairy Dairy Cattle through Acceleration of Complete Feed Technology Made from Local and Cheap Raw in Enrekang Regency. Faculty of Animal Science, Hasanuddin University, Makassar.

[14]Sirajuddin, S.N., A. Asnawi, I. Rasyid, A. Mangalisu, Masnur, 2016. Competitiveness of Beef Cattle Fattening in KuloSubdistrict, Sidrap District South Sulawesi Province. Advances Environmental of Biology(AEB) Journal., 10(1): 171-175.

[15]Singha, A.K., M.J. Baruah, R. Bardoloi, P. Dutta, U.S. Saikia, 2012. Analysis on Influencing Factors of Technology Adoption of Different Land Base Enterprises of Farmers under Diversified Farming System. Journal of Agricultural Science, 4(2): 139-145.

[16]Sirajuddin, S.N., A.R.Siregar, and P.Mappigau. 2017. Adoption Rate of Beef Farmers Technology Following Partnership System in Barru Regency. American-Eurasian Journal Of Sustainable Agriculture. ISSN: 1995-0748, EISSN: 1998-1074 2017, Volume (11), issue(6), pages(31-34), September 2017.

[17]Baba, S., Ja'far, A.Abdullah, M.I.A.Dagong, M.Azhar, and S.Sohrah. 2017. Effect of Attitude, Subjective Norm And Behaviour Control on Technology Adoption Rate of Goat Farmer. Advances In Environmental Biology. ISSN: 1995-0756, EISSN: 1998-1066. 11(12) pages 26-30. Desember 2017.

[18]Hasan, S. 2012. Dry/Critical Land Empowerment Through Integration of Ruminant Forage and Livestock Feed. Faculty of Animal Science, Hasanuddin University, Makassar.

[19]Rasyid, T.G., S.Hasan, S.Rasjid, and S.N.Sirajuddin. 2016. Development Model of Goat Farming Business Base On Productive Economy in Majene Regency, West Sulawesi, Indonesia. American-Eurasian Journal Of Sustainable Agriculture. ISSN:1995-0748, EISSN: 1998-1074 2016, volume(10), issue(3): pages(1-5). July 2016. 
[20]Rasyid, T.G., S.Hasan, S.Rasjid, and S.N.Sirajuddin. 2015. Accessibility Goat Livestock Cooperation With The Gover and Collecting Sulawesi Province. American-Eurasian Journal Of Sustainable Agriculture. ISSN: 1995-0748, EISSN: 1998-1074 2015, Volume (9), issue(7), pages(13-18). September 2015./

[21]Aminawar, M., Amrullah, ST.Rohani, I.Rasyid, and M.Darwis. 2018. Institutions in the Beef Cattle Farmers Group in Bone Regency, South Sulawesi Province. Proceedings of the National Postgraduate Seminar Faculty of Animal Science, Padjadjaran University, 3 Mei 2018, Sumedang, Indonesia; 333-343. ISBN: 978602-74116-6-1.

[22]Syahyuti. 2007. Policy for the Development of Farmers Group Combinations as Economic Institutions in Rural Areas. Center for Agricultural Socio Economic and Policy Analysis. http://pse.litbang.deptan.go.id/ind/pdffiles/ISU5-1b.pdf.

[23]Harjono. 2000. Farmer Group Business. PT. Gramedia Pustaka Utama, Jakarta.

[24]Irfan, Z. 2007. Development of Livestock Business Groups. http://www.disnakkeswan.lampung.go.id/publikasi/integrasi.pdf.

[25]Salman, D. 2012. Institutional Sustainability. Material for Institutional Lecture on Agricultural Development, S-3 Program. Pasacgraduate University of Hasanuddin, Makassar. 